\title{
Literasi Digital terhadap Perilaku Penggunaan Internet Berkonten Islam di Kalangan Remaja Muslim Kota
}

\author{
Millenia Prihatini ${ }^{1}$, Abdul Muhid ${ }^{2 *}$ \\ UIN Sunan Ampel Surabaya \\ 1'millenniza@gmail.com, 2abdulmuhid@uinsby.ac.id \\ *Correspondence
}

\section{Article Information:}

Received 29 August 2020

Revised 11 October 2020

Accepted 03 December 2021

Keywords:

Behavior; Digital; Literacy;

Muslim youth; Urban

\section{Kata Kunci:}

Digital; Literasi; Perilaku; Remaja muslim; Perkotaan
Internet as media and information technology not only has a positive impact but also harms its users. Teenagers are the most vulnerable group that has an impact on internet use. The impact of using the internet depends on the digital literacy level of its users. This study examines digital literacy's effect on using the internet with Islamic content among urban Muslim teenagers. This study uses a quantitative approach with a survey method. The research subjects were 500 urban adolescents as the research sample. Measuring instruments used in this study are the Digital Literacy Scale for Teenagers to measure digital literacy and the Internet Behaviors Scale to measure internet usage behavior. The result showed that digital literacy had a significant positive effect on internet usage behavior $(B=0.314 ; t=13.602 ; p=0.000)$. The higher level of digital literacy of adolescents automatically makes the higher behavior in using the internet shows that digital literacy is important for using the internet with Islamic content among urban Muslim teenagers.

Abstrak
Internet sebagai media dan teknologi informasi tidak hanya berdampak positif, tetapi juga berdampak negatif bagi penggunanya. Remaja merupakan kelompok yang paling rentan terhadap dampak penggunaan internet. Dampak penggunaan internet sangat tergantung pada tingkat literasi digital para penggunanya. Penelitian ini menguji pengaruh literasi digital dengan perilaku penggunaan internet berkonten Islam di kalangan remaja muslim kota. Penelitian ini menggunakan pendekatan kuantitatif dengan metode survei. Subyek penelitian berjumlah 500 orang remaja kota sebagai sample penelitian. Alat ukur yang digunakan dalam penelitian ini adalah Digital Literacy Scale for Teenagers untuk mengukur tingkat literasi digital dan Internet Behaviors Scale untuk mengukur perilaku penggunaan internet. Hasil penelitian menunjukkan adanya pengaruh positif yang signifikan literasi digital terhadap perilaku penggunaan internet $(B=0.314 ; t=13.602 ; p=0.000)$. Artinya, semakin tinggi tingkat literasi digital remaja maka semakin tinggi pula perilaku penggunaan internet. Hal ini menunjukkan bahwa peran literasi digital sangat penting mempengaruhi perilaku penggunaan internet berkonten Islam di kalangan remaja muslim kota. 


\section{PENDAHULUAN}

Perkembangan teknologi informasi saat ini sudah semakin cepat sehingga turut serta dalam kehidupan manusia sehari-hari mulai dari orang dewasa, remaja sampai anak-anak pun tak ketinggalan untuk mengikuti perkembangan zaman yang begitu pesat ini (Ihsan, 2016). Berkembangnya ilmu pengetahuan dan teknologi telah memunculkan pandangan baru dalam masyarakat, baik dalam bentuk ide dan pikiran maupun dalam perilaku nyata dalam kehidupan sehari-hari. Melalui media internet, maka dunia seperti cyberspace yang berarti tidak ada batas tempat dan waktu dalam mengakses segala informasi (Almilia, 2009).

Sekarang ini teknologi media sosial juga hadir karena dorongan dari kebutuhan masyarakat seperti kebutuhan aspek emosional, identitas diri, sosial, kognitif maupun kebiasaan (Nicolaou et al., 2019). Para pengguna sosial media yang mampu memanfaatkan media digital ini dengan baik maka dapat meningkatkan prestasi, sebaliknya bagi para pengguna yang tidak mampu memanfaatkan media digital dengan baik maka akan berdampak buruk bagi dirinya sendiri (Retnowati, 2015). Situasi ini menurut Koutamanis et al., (2017), bahwa media digital akan secara otomatis dapat mengubah cara manusia berkomunikasi atau bersosialisasi. Melalui media digital ini, para pengguna dapat memperdalam pengetahuan yang ada di dalam media tersebut, di samping itu media digital juga dapat digunakan sebagai media untuk membangun hubungan sosial atau pertemanan dalam dunia maya (Rose \& Rudolph, 2006).

Internet memberikan kemudahan dalam menjangkau wilayah geografis yang lebih luas, dengan biaya yang lebih murah namun aksestabilitas yang cepat dan akurat. Penyajian informasi bisnis dan keuangan berbasis internet juga dapat dilakukan dengan lebih fleksibel dan dapat disesuaikan dengan kebutuhan pengguna untuk mendukung keputusan bisnis mereka (Sukanto, 2011). Penggunaan internet ini menyebabkan pelaporan keuangan yang lebih cepat dan mudah dalam pelaporannya, karena pengguna internet dapat diakses oleh semua orang (Debreceny et al., 2002).

Menurut Hapsari \& Ghozali (2006) bahwa dengan berkembangnya teknologi digital berdampak pada perkembangan yang lebih cepat dan menimbulkan adanya perubahan lingkungan yang semakin meningkat. Sehingga peran lingkungan menjadi sangat penting dalam hubungan antar manusia, dan menjadi penentu perkembangan individu di dalam masyarakat yang mempunyai keberagaman ataupun budaya serta faktor yang menjadi interaksi milenial (Asmuni, 2019). Di sisi lain, media digital ini digunakan oleh para remaja untuk mencari tokoh identifikasi yang menjadi teladan dan menjadi role model, di saat bersamaan karena para pelajar juga merasa kesulitan dalam mencari figur keteladanan dari gurunya (Mucharomah, 2017).

Hal ini menjadi tantangan bagi remaja milenial dalam mengontrol diri supaya dapat berfikir dan bertindak secara positif, dan lebih fleksibel dalam beradaptasi terhadap perubahan yang ada (Asmuni, 2019). Kemampuan tersebut menjadi tolak ukur dari keberhasilan dan prestasi para remaja dalam pengembangan proses belajar 
(Sukmadinata, 2003). Oleh karena itu pendidikan bagi para remaja adalah hal terpenting dalam peningkatan kualitas sumber daya manusia. Para remaja dapat mengembangkan pendidikannya sebagai bekal di masa depan, karena dengan pendidikan kehidupan dapat menjadi lebih baik (Listyanto \& Munadi, 2013). Untuk itu para remaja dituntut untuk meningkatkan prestasi melalui belajar aktif seperti penggunaan internet sebagai media pencarian sumber-sumber belajar. Salah satu sumber belajar adalah dengan media internet.

Namun, di sisi lain dampak penggunaan internet yang tanpa kontrol megakibatkan banyak para penggunanya terpapar berbagai faham yang berbahaya bagi perkembangan remaja, seperti faham radikalisme. Sebab tidak hanya masalah narkoba, perkelahian antar remaja dan perilaku kenakalan remaja lainnya, namun remaja juga rentan terhadap masalah radikalisme agama (Widyaningsih et al., 2017). Masalahmasalah tersebut sangat berbahaya bagi masa depan mereka dan bangsa. Para pengguna media digital ini bertujuan untuk menjadikan media sebagai alat multifungsi baik digunakan untuk berkomunikasi, perkenalan, berbisnis online, dan mengambil maupun mengelola informasi yang sangat penting untuk diketahui dan dipelajari dalam meningkatkan pengetahuan remaja (Ainiyah, 2018).

Sebagaimana yang diungkapkan oleh Asrori et al. (2019), bahwa semakin meningkatnya penggunaan media internet, remaja millenial dapat menciptakan banyak masalah dan menciptakan gaya baru dalam berkomunikasi. Hal ini disebabkan karena di dunia digital dipenuhi konten-konnten yang berbahaya bagi perkembangan remaja. Di sisi lain, menurut Rahmatullah \& Said (2019) bahwa ilmu pengetahuan yang berasal dari media digital (internet) berdampak juga secara positif, karena akan menciptakan rasa ingin tahu dan meningkatkan pengetahuan penggunanya. Rasa ingin tahu yang tinggi bagi remaja milenial merupakan suatu tahap perkembangan yang tidak bisa dihindari, karena perubahannya yang semakin meningkat pesat (Perdana, 2019).

Media digital merupakan jaringan akses komputer yang sudah sangat besar, karena terdiri dari jaringan-jaringan yang saling berhubungan satu sama lainnya yang akan menjangkau seluruh dunia (Nurliah, 2018). Menurut Wahab (2016) internet merupakan suatu jaringan akses yang sudah berkembang cepat dan besar yang diantaranya memiliki perangkat-perangkat komputer yang saling berhubungan satu protokol dengan protokol lainnya yang terdapat pada komputer. Menurut Kuss \& Griffiths (2011) penggunaan media digital melalui jaringan internet akan menjadi fenomena global. Komunikasi dapat mudah terjangkau meskipun jaraknya yang jauh secara geografis. Teknologi digital ini memiliki fungsi secara positif bagi kenyamanan setiap individu yang menggunakannya. Di samping itu, media ini juga digunakan untuk berinteraksi dengan banyak orang di dunia maya. Dengan demikian, fenomena penggunaan media digital ini mempengaruhi perilaku manusia, salah satunya adalah perilaku adiksi media sosial (Maheswari \& Dwiutami, 2013). Adiksi media sosial merupakan masalah baru yang perlu di perhatikan oleh para peneliti. Media digital yang 
secara umum ini dapat digunakan secara berkepanjangan dalam durasi kehidupan sehari-hari berdampak pada pekerjaan, pendidikan, hubungan sosial, kesejahteraan, dan kesehatan psikologis manusia (Schou Andreassen \& Pallesen, 2014).

Kelompok remaja merupakan kelompok yang paling rentan terpapar pengaruh buruk dari media digital (Nur, 2019). Media digital dapat menimbulkan beberapa dampak buruk yang dapat mempengaruhi psikologis para remaja, diantaranya mengakibatkan timbulnya sikap iri terhadap sesama, depresi, selalu negative thingking dan mengakibatkan remaja terbiasa mengungkapkan bahasa-bahasa yang tidak sopan (Pratiwi \& Pritanova, 2017). Dampak penggunaan internet juga mempengaruhi komunikasi antara orang tua dengan para remaja, Hal ini disebabkan adanya potensi kecanduan tehadap internet hingga membuat para penggunanya melupakan kewajibannya dan tanggung jawab, karena tidak mampu mengatur waktu secara produktif (Tas \& Öztosun, 2018). Fenomena penyalahgunaan ini juga akan memiliki banyak sekali dampak buruk karena ada banyak sekali konten-konten yang terdapat di internet yang tidak pantas untuk dilihat dan sangat berbahaya bagi anak dibawah umur (Khotijah, 2015). Penyalahgunaan ini juga akan menimbulkan penyebaran hoax secara luas dan menimbulkan penipuan bagi para pengguna internet. Oleh karena itu dibutuhan literasi digital bagi para pengguna internet, khususnya di kalangan remaja.

Mustofa \& Budiwati (2019) mengatakan bahwa literasi digital diartikan sebagai skill memahami, menganalisis, mengatur, mengevaluasi informasi dengan memakai teknologi digital. Rata-rata media yang remaja gunakan untuk mengakses informasi digital adalah personal komputer, laptop, dan smartphone (Benaziria, 2018). Dengan semakin banyaknya remaja yang mengeksplorasi berbagai bentuk teknologi digital, berbagai instansi di bidang pendidikan berusaha mencari cara yang efektif untuk memanfaatkan media digital untuk meningkatkan pembelajaran siswa (Muyasaroh et al., 2020; S.A.P. et al., 2020; Vu et al., 2019). Secara tidak langsung remaja usia sekolah sangat membutuhkan literasi digital. Temuan Jang et al., (2018) menunjukkan bahwa literasi digital telah memberi kontribusi besar pada pemahaman remaja, karena literasi media dapat mengembangkan aspek kognitif, afektif, dan sosiokultural khususnya dalam literasi di berbagai lingkungan digital.

Salah satu faktor yang menyebabkan pentingnya literasi digital bagi remaja adalah kemudahan dalam akses informasi secara cepat, tepat, dan dalam jumlah yang tidak terbatas (Nurjanah et al., 2017). Manfaat lain yang diperoleh remaja adalah mereka dapat terhubung setiap saat baik dengan teman maupun guru di manapun berada, siswa dapat melakukan berbagai kegiatan seperti mencari informasi yang diperlukan, berkolaborasi antar teman, membuat, berbagi dan mendistribusikan materi secara online serta mendapatkan akses hiburan dan pendidikan yang lebih kompleks melalui media seperti musik, video, film, program TV, surat kabar online, dan buku virtual (Nicholas $\& \mathrm{Ng}, 2019)$. McLean (2010) menyatakan bahwa para remaja sering menggunakan media informasi digital seperti internet sebagai sarana yang memungkinkan mereka 
untuk mendapatkan informasi terbaru dengan bahasa, gaya, dan kebiasaan mereka sehari-hari. Keterlibatan media digital di lingkungan pendidikan dapat mengembangkan potensi peserta didik yaitu: (1) memperluas keterlibatan aktif antara waktu dan tugas siswa melalui diskusi secara online; (2) mengorganisir keterlibatan kognitif siswa melalui pertanyaan untuk meningkatkan pemahaman teks online; dan (3) memfasilitasi keterlibatan afektif dengan membangkitkan antusiasme dan keinginan siswa untuk menjadi bagian dari kelompok literasi yang lebih luas dan kompleks (Hunter et al., 2018).

Berdasarkan penjelasan tersebut di atas dapat dipahami bahwa dalam aktivitas sehari-hari para remaja tidak bisa lepas dari penggunaan media digital. Salah satu media digital yang sering digunakan oleh para remaja muslim kota dalam mencari informasi tentang Islam adalah media internet. Media internet berkonten Islam yang banyak menyajikan berbagai macam informasi tentang Islam menjadi media yang sangat penting terhadap pengetahuan kegamaan para remaja muslim kota. Hal itu seiring dengan menguatnya tingkat literasi digital di kalangan generasi milenial seperti remaja muslim kota ini. Oleh karena itu, perlu penelitian untuk menguji apakah ada pengaruh literasi digital dengan perilaku penggunaan internet khususnya dalam mengakses situs berkonten Islam sebagai akibat dari perkembangan teknologi di kalangan remaja muslim kota.

\section{METODE}

Penelitian ini menggunakan pendekatan kuantitatif dengan desain kausalitas korelasional. Metode survei digunakan untuk mengumpulkan data dengan menyebarkan instrumen kepada para partisipan. Penelitian ini dilakukan pada remaja muslim kota Surabaya dengan rentang usia 15 sampai dengan 19 tahun (Tabel 1). Kota Surabaya ditetapkan sebagai lokasi penelitian, karena di samping sebagai kota metropolitan Surabaya juga merupakan kota pendidikan dengan jumlah para remaja yang bersekolah dan berpendidikan tinggi di universitas sangat banyak. Penelitian ini menggunakan non probability sampling dengan teknik sampling purposive, di mana subyek penelitian disesuaikan dengan kriteria penelitian yaitu para remaja muslim pengguna aktif internet yang menggunakan media internet untuk mencari informasi dan memahami ajaran Islam melalui situs-situs bernuansa Islam.

Alat ukur psikologi yang digunakan dalam penelitian ini adalah 2 skala psikologis, yaitu sebagai berikut: Pertama, Skala Literasi Digital (S-LD), instrumen ini adaptasi dari Digital Literacy Scale for Teenagers yang disusun sebelumnya oleh Rodríguez-De-dios, Igartua, \& González-Vázquez (2016) terdiri atas 6 aspek, yaitu: (1) aspek keterampilan teknologi digital; (2) aspek keterampilan keamanan personal; (3) aspek keterampilan berfikir kritis; (4) aspek keterampilan keamanan perangkat digital; (5) aspek keterampilan mencari informasi; dan (6) aspek keterampilan komunikasi. Skala ini terdiri atas 29 aitem dengan nilai koefisien reliabilitas yang tinggi $(\alpha=.878)$. Kedua, Skala 
Perilaku Penggunaan Internet (S-PPI), instrumen ini adaptasi dari Internet Behaviors Scale yang disusun sebelumnya oleh Ranaiey, Taghavi, \& Goodarzi (2016) terdiri atas 3 aspek, yaitu: (1) aspek sosial; (2) dampak negatif; dan aspek kompetensi dan kenyamanan.

Adaptasi bahasa dan budaya digunakan dalam pengembangan kedua instrumen penelitian tersebut, antara lain melalui tahapan sebagai berikut: (1) penerjemahan instrumen oleh dua orang profesional alih bahasa; (2) hasil terjemahan selanjutnya direview oleh dua psikolog; (3) hasil review oleh psikolog tersebut selanjutnya disusun menjadi aitem; (4) aitem-aitem yang telah disusun selanjutnya dibaca oleh 5 orang remaja; (5) masukan dari pembaca selanjutnya digunakan untuk merevisi aitem; (6) instrument diuji cobakan kepada 50 remaja pengguna internet; dan (7) hasil seleksi aitem siap digunakan untuk instrumen penelitian. Analisis regresi sederhana digunakan untuk menganalisis data penelitian yakni dengan melihat kausalitas antara literasi digital dengan perliaku penggunaan internet pada remaja. Seluruh analisis data menggunakan SPSS Program for Windows Versi 20.

\section{PAPARAN HASIL HASIL}

Setelah diseleksi sesuai dengan kriteria sebagai subyek penelitian, diperoleh 500 orang remaja sebagai sampel penelitian. Tabel 1 menunjukkan distribusi partisipan.

Tabel 1. Data Demografi

\begin{tabular}{clcc}
\hline Kriteria & \multicolumn{1}{c}{ Demografi } & Frekuensi & Persentase \\
\hline \multirow{2}{*}{ Gender } & Laki-laki & 273 & $54.60 \%$ \\
& Perempuan & 227 & $55.40 \%$ \\
& 15 Tahun & 49 & $9.80 \%$ \\
& 16 Tahun & 88 & $17.60 \%$ \\
& 17 Tahun & 167 & $33.40 \%$ \\
& 18 Tahun & 120 & $24 \%$ \\
& 19 Tahun & 76 & $15.20 \%$ \\
Pendidikan & SMP & 42 & $8.40 \%$ \\
& SMA & 393 & $78.60 \%$ \\
& Perguruan Tinggi & 65 & $13 \%$ \\
Waktu & 1-3 Jam/Hari & 40 & $8 \%$ \\
Internet & 7-6 Jam/Hari & 89 & $17.80 \%$ \\
& $10-12$ Jam/Hari & 199 & $39.80 \%$ \\
& $>12$ Jam/Hari & 104 & $20.80 \%$ \\
\hline
\end{tabular}

Tabel 1 menunjukkan data demografi dari remaja di Kota Surabaya, dengan jumlah laki-laki sebanyak 273 orang atau sebesar 54.6 persen dan perempuan sebanyak 227 orang atau sebesar 55.4 persen. Kemudian dari kategori usia, terlihat bahwa jumlah remaja di Kota Surabaya terbanyak pada usia 17 tahun sebanyak 167 orang atau sebesar 33.4 persen. Selanjutnya dari kategori pendidikan, terlihat bahwa mayoritas jumlah 
remaja di Kota Surabaya terbanyak berada pada tingkat SMA sebanyak 393 orang atau sebesar 78.6 persen. Selanjutnya, berdasarkan waktu penggunaan internet, maka dapat disimpulkan bahwa pada remaja mayoritas menghabiskan waktu untuk menggunakan internet selama 7-9 Jam/Hari berjumlah 199 orang atau 39.8 persen.

Pengaruh literasi digital terhadap perilaku penggunaan internet berkonten Islam pada remaja muslim di Kota Surabaya dengan analisis data menggunakan analisis regresi sederhana.

Tabel 2. Hasil Analisis Regresi Sederhana antara Literasi Media terhadap Perilaku Penggunaan Internet

\begin{tabular}{|c|c|}
\hline Statistic & Value \\
\hline$F$ & 185.026 \\
\hline$P$ & 0.000 \\
\hline$R$ & 0.520 \\
\hline$R$ Square & 0.271 \\
\hline
\end{tabular}

Hasil analisis statistik pada tabel 2 menunjukkan bahwa ada pengaruh positif antara kedua variabel yaitu literasi digital dan perilaku penggunaan internet ( $F=185.026$; $P=0.000$ ). Penelitian ini membuktikan bahwa literasi digital merupakan prediktor yang signifikan terhadap perilaku penggunaan internet untuk mengakses situs berkonten Islam pada remaja. Pengaruh literasi digital sebesar $27.1 \%$ terhadap perilaku penggunaan internet, $72.9 \%$ dipengaruhi oleh variabel lain.

\section{Tabel 3. Pengaruh Literasi Media terhadap Perilaku Penggunaan Internet}

\begin{tabular}{lccc}
\hline \multicolumn{1}{c}{ Variabel Prediktor } & $B$ & $T$ & $P$ \\
\hline Konstanta & 17.64 & 16.628 & 0 \\
Literasi Digital & 0.314 & 13.602 & 0 \\
\hline
\end{tabular}

Tabel 3 menunjukkan hasil dimana variabel literasi digital memiliki pengaruh positif yang signifikan terhadap perilaku penggunaan internet $(B=0.314 ; t=13.602$; $p=0.000$ ). Berdasarkan table 3 tersebut, maka dapat disusun persamaan regresi linier pada penelitian ini adalah sebagai berikut:

$\mathrm{Y}^{\prime}=\mathrm{a}+\mathrm{b}_{1} \mathrm{X}_{1}$

$Y^{\prime}=17.64+(0.314) X_{1}$

$Y^{\prime}=17.64+0.314$

Keterangan:

$\mathrm{Y}^{\prime}=$ perilaku penggunaan internet

a $=$ konstanta

$\mathrm{b}_{1}=$ koefisien regresi

$\mathrm{X}_{1}=$ literasi digital

Berdasarkan persamaan regresi tersebut dapat dijelaskan sebagai berikut: (1) konstanta sebesar 17.64, artinya jika literasi digital $\left(\mathrm{X}_{1}\right)$ nilainya adalah 0 , maka perilaku penggunaan internet (Y') nilainya adalah 17.64; (2) koefisien regresi variabel literasi digital $\left(\mathrm{X}_{1}\right)$ sebesar 0.314 , artinya jika variabel prediktor literasi digital mengalami 
kenaikan nilai 1, maka skor perilaku penggunaan internet mengalami kenaikan sebesar 0.314. Artinya, semakin tinggi tingkat literasi digital yang dilakukan oleh remaja maka semakin tinggi pula perilaku penggunaan internet. Dengan demikian, variabel literasi digital dapat dijadikan sebagai variabel prediktor terhadap perilaku penggunaan internet pada remaja.

Selain itu, temuan penelitian ini juga memberikan informasi tambahan dengan menggunakan analisis uji beda berdasarkan data demografi. Data demografi sebagaimana yang dipaparkan pada hasil penelitian tersebut di atas maka dapat dijelaskan secara lebih terinci terkait dengan tingkat literasi digital dan perilaku penggunaan internet berkonten Islam sesuai dengan jenis kelamin, usia, kategori pendidikan, dan berdasarkan waktu penggunaan internet.

Pertama, berdasarkan data demografi menurut jenis kelamin ditemukan bahwa para responden remaja muslim kota Surabaya diperoleh responden yang berjenis kelamin laki-laki sebanyak 273 orang dan perempuan sebanyak 227 orang. Berdasarkan hasil uji-t dua sampel saling bebas (independent samples t-test) menunjukkan bahwa rata-rata skor literasi digital pada kelompok responden lak-laki $=42.3199(S D=10.089)$; perempuan $=47.7544(S D=$ 9.887), dengan harga $F=.023 ; t=-6.065$ dengan $P=.000(<.05)$. Artinya ada perbedaan yang signifikan rata-rata tingkat literasi digital antara remaja muslim laki-laki dan remaja muslim perempuan. Dilihat dari rata-rata skor literasi digital pada kedua kelompok jenis kelamin menunjukkan bahwa rata-rata skor literasi digital remaja muslim perempuan lebih tinggi dibanding rata-rata skor literasi digital remaja muslim laki-laki. Berdarasarkan hasil ujit dua sampel saling bebas (independent samples $t$-test) menunjukkan bahwa rata-rata skor perilaku penggunaan internet pada kelompok responden lak-laki $=30.6618(S D=6.27267)$; perempuan $=32.9386(S D=5.98351)$, dengan harga $F=.245 ; t=-4.128$ dengan $P=.000(<$ .05). Artinya ada perbedaan yang signifikan rata-rata perilaku penggunaan internet antara remaja muslim laki-laki dan remaja muslim perempuan. Dilihat dari rata-rata skor perilaku penggunaan internet pada kedua kelompok jenis kelamin menunjukkan bahwa rata-rata skor perilaku penggunaan internet remaja muslim perempuan lebih tinggi dibanding rata-rata skor perilaku penggunaan internet remaja muslim laki-laki.

Kedua, berdasarkan data demografi menurut kategori usia menunjukkan bahwa responden berusia dengan rentang antara 15 tahun sampai dengan 20 tahun. Berdasarkan hasil analisis varian satu arah (one-way ANOVA) menunjukkan bahwa rata-rata skor literasi digital pada kelompok responden berusia 15 tahun $=43.8974(S D=11.53209)$; usia 16 tahun $=$ $44.3202(S D=11.18482)$; usia 17 tahun $=49.3741(S D=9.19536)$; usia 18 tahun $=43.1731$ $(S D=7.60217)$; usia 19 tahun $=39.9659(S D=8.00208)$, dengan harga $F=9.341$; dengan $P=$ $.000(<.05)$. Artinya ada perbedaan yang signifikan rata-rata tingkat literasi digital dilihat berdasarkan usia responden. Dilihat dari rata-rata skor literasi digital pada semua kelompok umur, menunjukkan bahwa remaja berumur 17 tahun yang paling tinggi rata-rata skor literasi digital, sedangkan remaja berumur 19 tahun yang paling rendah rata-rata skor literasi digital. Berdasarkan hasil hasil analisis varian satu arah (one-way ANOVA) menunjukkan bahwa rata- 
rata skor skor perilaku penggunaan internet pada kelompok responden berusia 15 tahun = $31.4103(S D=6.12466)$; usia 16 tahun $=30.4663(S D=6.39752)$; usia 17 tahun $=34.6691$ $(S D=6.23732)$; usia 18 tahun $=31.8846(S D=4.04705)$; usia 19 tahun $=29.3977(S D=$ 5.23810), dengan harga $F=9.564$; dengan $P=.000(<.05)$. Artinya ada perbedaan yang signifikan rata-rata perilaku penggunaan internet dilihat berdasarkan usia responden. Dilihat dari rata-rata skor perilaku penggunaan internet pada semua kelompok umur, menunjukkan bahwa remaja berumur 17 tahun yang paling tinggi rata-rata skor perilaku penggunaan internet, sedangkan remaja berumur 19 tahun yang paling rendah rata-rata skor perilaku penggunaan internet.

Ketiga, berdasarkan data demografi menurut latar belakang pendidikan menunjukkan bahwa responden berpendidikan SMP (8.4\%), berpendidikan SMA (78.6\%), dan perguruan tinggi (13\%). Berdasarkan hasil analisis varian satu arah (one-way ANOVA) menunjukkan bahwa rata-rata skor literasi digital pada kelompok responden berpendidikan SMP $=39.6863$ $(S D=8.27635)$; $S M A=43.5731(S D=8.43215)$; perguruan tinggi $=45.3202(S D=11.16483)$, dengan harga $F=9.827$; dengan $P=.000(<.05)$. Artinya ada perbedaan yang signifikan ratarata tingkat literasi digital dilihat berdasarkan latar belakang pendidikan. Dilihat dari rata-rata skor literasi digital berdasarkan latar belakang pendidikan, menunjukkan bahwa responden yang berpendidikan perguruan tinggi yang paling tinggi rata-rata skor literasi digital, sedangkan responden berpendidikan SMP yang paling rendah rata-rata skor literasi digital. Berdasarkan hasil hasil analisis varian satu arah (one-way ANOVA) menunjukkan bahwa ratarata skor skor perilaku penggunaan internet berdasarkan latar belakang pendidikan SMP = 38.47521 $(S D=8.27635)$; $\mathrm{SMA}=42.3202(S D=10.16483)$; perguruan tinggi $=43.1731(S D=$ 7.60217), dengan harga $F=9.827$; dengan $P=.000(<.05)$. Artinya ada perbedaan yang signifikan rata-rata perilaku penggunaan internet dilihat berdasarkan latar belakang pendidikan. Dilihat dari rata-rata skor perilaku penggunaan internet berdasarkan latar belakang pendidikan, menunjukkan bahwa bahwa responden yang berpendidikan perguruan tinggi yang paling tinggi rata-rata skor perilaku penggunaan internet, sedangkan responden berpendidikan SMP yang paling rendah skor perilaku penggunaan internet.

Keempat, berdasarkan waktu penggunaan internet, maka dapat disimpulkan bahwa remaja menghabiskan waktu untuk menggunakan internet selama 1-3 jam/hari $=8 \%$; 4-6 $\mathrm{jam} / \mathrm{hari}=17.8 \% ; 7-9 \mathrm{jam} / \mathrm{hari}=39.8 \% ; 10-12 \mathrm{jam} / \mathrm{hari}=20.8 \%$; dan $>12 \mathrm{jam} / \mathrm{hari}=12.6 \%$. Berdasarkan hasil analisis varian satu arah (one-way ANOVA) menunjukkan bahwa rata-rata skor literasi digital pada kelompok responden yang menggunakan internet selama 1-3 jam/hari $=44.6905(S D=12.20253)$; selama 4-6 jam/hari = 43.3426 $(S D=10.09503)$; selama 7-9 $\mathrm{jam} /$ hari $=46.9612(S D=10.20907)$; selama 10-12 jam/hari $=44.8710(S D=10.01437)$; selama $>12 \mathrm{jam} / \mathrm{hari}=43.8281(S D=10.08242)$, dengan harga $F=2.249 ;$ dengan $P=.006$ $(<.05)$. Artinya ada perbedaan yang signifikan rata-rata tingkat literasi digital dilihat berdasarkan waktu penggunaan internet. Dilihat dari rata-rata skor literasi digital pada semua kelompok waktu penggunaan internet, menunjukkan bahwa remaja yang menghabiskan waktu untuk menggunakan internet selama 7-9 jam/hari yang paling tinggi rata-rata skor 
literasi digital, sedangkan remaja yang menghabiskan waktu untuk menggunakan internet selama 4-6 jam/hari yang paling rendah rata-rata skor literasi digital. Berdasarkan hasil analisis varian satu arah (one-way ANOVA) menunjukkan bahwa rata-rata skor perilaku penggunaan internet pada kelompok responden yang menggunakan internet selama $1-3 \mathrm{jam} / \mathrm{hari}=30.0238$ $(S D=7.61734)$; selama 4-6 jam/hari $=31.8241(S D=5.74998)$; selama 7-9 jam/hari $=32.8372$ $(S D=6.30326)$; selama 10-12 jam/hari $=33.8925(S D=5.55694)$; selama $>12$ jam/hari $=$ $35.9766(S D=6.28893)$, dengan harga $F=3.719$; dengan $P=.000(<.05)$. Artinya ada perbedaan yang signifikan rata-rata perilaku penggunaan internet dilihat berdasarkan waktu penggunaan internet. Dilihat dari rata-rata skor perilaku penggunaan internet pada semua kelompok waktu penggunaan internet, menunjukkan bahwa remaja yang menghabiskan waktu untuk menggunakan internet selama > 12 jam/hari yang paling tinggi rata-rata skor perilaku penggunaan internet, sedangkan remaja yang menghabiskan waktu untuk menggunakan internet selama 1-3 jam/hari yang paling rendah rata-rata skor perilaku penggunaan internet.

\section{PEMBAHASAN}

Penelitian ini membuktikan bahwa literasi digital merupakan prediktor yang signifikan terhadap perilaku penggunaan internet untuk mengakses situs berkonten Islam pada remaja. Kemampuan literasi digital para remaja muslim sangat berpengaruh terhadap perilaku penggunaan internet dalam mengakses situs berkonten Islam guna pemenuhan kebutuhan informasi dan pengetahuan keagamaan. Hal ini telah dibuktikan oleh Idris (2015) yang menyatakan bahwa melalui teknologi informasi seperti media internet, para remaja mampu menguasai pengetahuan tentang ajaran Islam. Tingkat literasi digital para remaja mempengaruhi kemandirian remaja dalam mencari informasi tentang materi keislaman di situs-situs Islam yang ada di internet. Hal itu juga sebagaimana menurut Darmaningrat, Ali, Wibowo, \& Astuti (2018) bahwa kemampuan literasi digital yang dimiliki para remaja mempermudah para remaja dalam mengkses sumber belajar secara interaktif dan menyenangkan.

Media digital seperti internet merupakan media informasi digital yang dapat diperoleh dengan mudah. Menurut Bawden (2001) mengungkapkan bahwa literasi digital merupakan konsep yang mencakup konsep literasi di era digital yang sudah muncul dari tahun 1990 sampai sekarang. Literasi digital dapat dijadikan sebagai tempat untuk melakukan pemahaman dan penggunaan informasi dari berbagai konsep format literasi yang ada. Konsep literasi bukan hanya mencakup kemampuan dalam membaca saja, tetapi juga dapat menjadi wadah untuk membaca dengan pemahaman yang luas (Lankshear \& Knobel, 2015).

Berkembangnya media digital adalah hal yang sangat penting bagi semua orang karena berhubungan dengan masa depan negara nantinya (Kanematsu \& Barry, 2016). Manusia yang belum dapat memahami dunia digital akan menimbulkan dampak penyalahgunaan media digital dan media sosial. Oleh sebab itu, perlu adanya peningkatan pembelajaran untuk para pelaku pendidikan di Indonesia (Suwarsito et al., 2011). Manfaat dari 
pendidikan itu sendiri untuk membentuk pribadi anak supaya menjadi manusia yang lebih baik sebagai masyarakat maupun menjadi warga negara yang lebih baik dan lebih bermanfaat kepada Negara (SP, 2003). Menurut Laksana (2015) mengutarakan bahwa para remaja perlu memiliki karakter positif sebagai proses pengembangan berpikir serta berperilaku untuk dapat bekerja sama baik dalam lingkungan keluarga, masyarakat, bangsa, dan negara.

Keinginan untuk mengetahui suatu hal ini menimbulkan adanya sifat remaja yang bersifat lebih permisif untuk melakukan perilaku yang tidak pantas dan melanggar hukum agama, dan membuat pemahaman agama menjadi faktor pembeda (Masni \& Hamid, 2018). Pertumbuhan Internet didorong oleh semakin baiknya kemudahan penggunaannya, biaya akses dan telekomunikasi yang makin murah, komputer yang semakin murah dan yang paling penting adalah meningkatnya jumlah informasi dan hiburan (Wahyuningtyas \& Widiastuti, 2015).

Gumgum et al. (2017) menyatakan bahwa literasi digital merupakan kemampuan dalam penggunaan teknologi dan informasi digital yang secara efektif dan efisien dalam berbagai konteks akademik dan menjadi pertukaran informasi yang cepat dan mudah di dalam kehidupan sehari-hari. Literasi digital juga merupakan bentuk pola berpikir pengguna digital yang menawarkan pemahaman terkait literasi komputer dan literasi informasi (Bawden, 2001). Literasi digital yang semakin berkembang ini pada akhirnya menciptakan dua sisi yang berkaitan. Perkembangan alat-alat literasi digital serta akses informasi ini mempunyai hambatan maupun peluang. Adanya media digital ini membuat manusia dapat memanfaatkannya dalam berbagai hal yakni saling bertukar informasi tanpa batas tempat dan waktu (Mendayun \& Sjuchro, 2018).

Para remaja maupun masyarakat perlu berfikir bahwa betapa pentingnya penggunaan media literasi digital ini karena dapat membantu beberapa hal yang penting yang hanya terdapat di media digital (Livingstone et al., 2008). Perkembangan teknologi informasi dan komunikasi telah memberikan pengaruh terhadap dunia pendidikan khususnya dalam proses pembelajaran. Di sekarang ini, Perkembangan teknologi juga mengalami kemajuan teknologi informasi dan komunikasi. Sehingga membuat perkembangan internet menjadi semakin berkembang pesat (Kusuma \& Sugandi, 2019).

Di Indonesia masa ini, mengalami perkembangan media yang sangat pesat, yaitu kirakira ada 43.400 media (Wulandari, 2013). Hingga para pengguna yang ingin memanfaatkan teknologi informasi digital ini sudah sangat mudah untuk memperoleh informasi, karena sudah banya media-media digital internet yang tersedia. Baik itu media yang sudah tercatat resmi dan media yang tercatat belum resmi. Dari hal ini juga menyebabkan para remaja untuk terfokus ke media yang sudah ada, dan sudah mulai melupakan membaca secara langsung, misalnya buku (Silvana \& Darmawan, 2018). Setiap para remaja maupun para penggunaan lainya harus memaknai literasi digital ini, karena merupakan pusat informasi yang juga penting, serta dibutuhkan dalam partisipasi dunia millenial sekarang. Literasi digital juga berperan sebagai media untuk membaca, menulis, dan lainnya (Ainiyah, 2018).

Hasil pengujian statistik menunjukkan bahwa penelitian ini membuktikan bahwa 
literasi digital merupakan prediktor yang signifikan terhadap perilaku penggunaan internet. Penelitian ini menunjukkan bahwa terdapat pengaruh positif yang signifikan antara variabel literasi digital terhadap perilaku penggunaan internet. Artinya semakin tinggi tingkat literasi digital remaja maka semakin tinggi perilaku penggunaan internet, sebaliknya semakin rendah literasi literasi digital remaja maka semakin rendah perilaku penggunaan internet. Hal ini menunjukkan bahwa peran literasi digital sangat penting mempengaruhi perilaku penggunaan internet berkonten Islam di kalangan para remaja muslim kota Surabaya. Temuan penelitian ini juga menunjukkan bahwa para remaja muslim kota Surabaya sudah cukup tinggi tingkat literasi digital sehingga mereka dengan mudah menggunakan internet untuk mengakses dan mendapatkan informasi tentang Islam.

Temuan penelitian ini mendukung penelitian-penelitian sebelumnya seperti Saputra (2018) yang menyatakan bahwa akses informasi melalui media internet memungkinkan terjadinya proses belajar yang lebih luas dan kompleks menggunakan media internet. Remaja yang memiliki rasa ingin tahu tinggi akan mengakses situs untuk kegiatan membaca dan melihat update terkini melalui dunia internet. Sedangkan temuan Hakim et al. (2016) bahwa para remaja yang lahir dan tumbuh dengan internet mempunyai pemikiran yang sangat berbeda dengan para remaja yang sebelumnya. Para pengguna teknologi informasi ini harus pandai dalam mempertanggung jawabkan pengaplikasiannya dalam menggunakan media digital ini untuk digunakan baik dalam berinteraksi, memperoleh informasi atau berkomunikasi di lingkungannya. Adapun Greene (2018) menyatakan bahwa media internet ini dapat memudahkan para guru dan siswa dalam berbagi informasi dalam bidang pembelajaran. Siswa di era milenial ini dituntut untuk mampu menemukan teks online, mengevaluasi sumber teks, dan membedakan web asli dari situs web palsu.

Termasuk kesadaran setiap individu yang harus dimiliki untuk dapat mengkritisi jika ada tindakan-tindakan yang tidak baik dalam penggunaan internet yang dilakukan oleh pengguna lainnya, baik itu kritis dampak positif maupun negatifnya (Mauludin et al., 2016). Para remaja yang menggunakan internet ini akan menjadi produsen aktif, jika para remaja maupun orang lain terus menerus menggunakan media digital atau internet. Perkembangan zaman juga menekankan kepada para pemuda, remaja, maupun orang dewasa ini untuk dapat menguasai teknologi modern, hal ini disebabkan karena media internet juga banyak menampilkan lowongan-lowongan untuk para pekerja, media ini juga digunakan dalam partisipasi demokrasi, maupun interaksi sosial (Lestari et al., 2018).

Menurut Spante et al. (2018) bahwasanya ada 8 (delapan) elemen esensial dalam pengembangan literasi digital, yaitu: (1) perlu mengandung nilai dalam penggunaan dunia digital; (2) mampu mempunyai pemikiran dalam menilai konten; (3) reka cipta harus sesuai dengan sesuatu yang nyata dan aktual; (4) harus mampu menggunakan dan mengaplikasikan jejaring dan komunikasi di dunia digital; (5) bertanggung jawab; (6) mampu menciptakan halhal baru dan pemikiran yang baru; (7) kritis dalm menilai konten-konten yang ada; dan (8) memiliki rasa tanggung jawab secara luas. Dari aspek-aspek ini sangat penting untuk para pengguna dalam memahami dan menilai suatu konten yang ada di media. Oleh karena itu, 
media digital merupakan sumber pengetahuan yang sangat luas yang ada dalam media digital.

Dengan adanya temuan penelitian ini berimplikasi pada pentingya peningkatan penggunaan literasi digital kepada para remaja, karena para remaja perlu memiliki sifat kritiskreatif dalam penggunaan media literasi digital. Menurut Jang et al. (2018) menunjukkan bahwa literasi digital telah memberi kontribusi besar pada pemahaman remaja, karena media literasi digital dapat mengembangkan aspek kognitif, afektif, dan sosiokultural khususnya dalam literasi di berbagai lingkungan digital. Pentingnya literasi digital bagi remaja yang lain adalah kemudahan dalam akses informasi secara cepat, tepat, dan dalam jumlah yang tidak terbatas (Nurjanah et al., 2017).

Goldman \& Scardamalia (2013) menyatakan bahwa perlu upaya untuk mengolah dan menyaring informasi bagi para pengguna yang menggunakan media literasi sesuai tujuan maupun fungsinya sehingga tidak akan termakan oleh isu-isu yang dapat memprovokasi keadaan, maupun menjadi korban dan pelaku dalam penyebaran berita hoax, dan tidak kecil peluang bagi mereka untuk dapat terjerumus dalam tindakan penipuan yang diakses di dalam internet. Oleh karena itu, perlu adanya pemantauan maupun nasehat dari para orang tua dalam penggunaan budaya media literasi digital yang digunakan para anak-anaknya, serta orang tua juga perlu berperan aktif dalam mendidik anak-anaknya dalam perkembangan teknologi modern sekarang ini (Pancarrani et al., 2017). Penggunaan media digital yang selektif dan diikuti oleh rasa keingintahuan remaja yang tinggi terhadap berbagai informasi berdampak pada motivasi belajar, aspek kognitif dan kreatifitas remaja (Jang et al., 2018). Remaja yang memiliki rasa keingintahuan yang tinggi terhadap hal baru cenderung memilih informasi secara instan sehingga kurang mengindahkan aspek norma dan etika saat berselancar di media digital sehingga perlu adanya skill dalam penggunaan literasi digital (Freeman et al., 2018). Selain itu, dengan adanya dukungan dan nasehat dari guru dan orang tua para remaja juga dapat mengembangkan potensi baik di bidang akademik maupun non akademik.

\section{SIMPULAN}

Berdasarkan penjelasan tersebut di atas, maka dapat disimpulkan bahwa ada pengaruh positif yang signifikan antara literasi digital dengan penggunaan internet berkonten Islam di kalangan remaja muslim kota. Artinya semakin tinggi tingkat literasi digital berpengaruh semakin tinggi pula perilaku penggunaan internet berkonten Islam di kalangan remaja muslim kota Surabaya. Penelitian ini membuktikan bahwa para remaja muslim kota Surabaya yang menggunakan media internet memiliki tingkat literasi digital yang cukup tinggi, sehingga mempengaruhi terhadap perilaku penggunaan internet. Temuan penelitian ini membuktikan kembali bahwa penggunaan internet sangat tergantung pada tingkat literasi digital para penggunanya. Oleh karena itu, temuan penelitian ini dapat dijadikan dasar bahwa literasi digital berperan sangat penting bagi para remaja muslim supaya memiliki sifat kritis-kreatif dalam penggunaan internet berkonten Islam. 


\section{DAFTAR PUSTAKA}

Ainiyah, N. (2018). Remaja Millenial dan Media Sosial: Media Sosial Sebagai Media Informasi Pendidikan Bagi Remaja Millenial. Jurnal Pendidikan Islam Indonesia, 2(2), 221-236. https://doi.org/10.35316/jpii.v2i2.76

Almilia, L. S. (2009). Analisa Komparasi Indeks Internet Financial Reporting pada Website Perusahaan Go Publik Di Indonesia. Seminar Nasional Aplikasi Teknologi Informasi (SNATI).

Asmuni, H. (2019). Peran Lingkungan Sosial terhadap Kontrol Diri Kaum Milenial. AlFikrah2, 2(2), 119-134.

Asrori, A., Bakhita, F., \& Aulia, R. (2019). Lunturnya Norma Pancasila di Era Milenial 2019/2020. Jurnal Ilmiah Profesi Pendidikan, 4(2), 83-90.

Bawden, D. (2001). Information and digital literacies: A review of concepts. Journal of Documentation, 57(2), 218-259.

Benaziria, B. (2018). Pengembangkan Literasi Digital pada Warga Negara Muda dalam Pembelajaran PPKn melalui Model VCT. Jupiis: Jurnal Pendidikan Ilmu-Ilmu Sosial, 10(1), 11-20.

Darmaningrat, E. W. T., Ali, A. H. N., Wibowo, R. P., \& Astuti, H. M. (2018). Pemanfaatan Aplikasi Digital Learning untuk Pembelajaran Pengayaan di Sekolah Menengah Kota Surabaya. Seminar Nasional Sistem Informasi Indonesia, (November), 85-95. Retrieved from http://is.its.ac.id/pubs/oajis/index.php/file/download_file/1828.

Debreceny, R., Gray, G. L., \& Rahman, A. (2002). The determinants of Internet financial reporting. Journal of Accounting and Public Policy, 21(4-5), 371-394.

Dewi, N., \& Trikusumaadi, S. K. (2017). Bahaya Kecanduan Internet dan Kecemasan Komunikasi terhadap Karakter Kerja Sama pada Mahasiswa. Jurnal Psikologi, 43(3), 220. https://doi.org/10.22146/jpsi.16829

Dwi Laksana, S. (2015). Urgensi Pendidikan Karakter Bangsa di Sekolah. Jurnal Muaddib, 5(2).

Freeman, J. L., Caldwell, P. H. Y., Bennett, P. A., \& Scott, K. M. (2018). How adolescents search for and appraise online health information: A systematic review. The Journal of Pediatrics, 195, 244-255.

Goldman, S. R., \& Scardamalia, M. (2013). Managing, understanding, applying, and creating knowledge in the information age: Next-generation challenges and opportunities. Cognition and Instruction, 31(2), 255-269.

Greene, K. (2018). Transferable Digital Literacy Knowledge. The Language and Literacy Spectrum, 28(1), 3.

Gumgum, G., Justito, A., \& Nunik, M. (2017). Literasi Media: Cerdas Menggunakan Media Sosial dalam Menanggulangi Berita Palsu (Hoax) oleh Siswa SMA. Pengabdian Kepada Masyarakat, 1(1), 35-40. https://doi.org/1410 - 5675

Hakim, S. N., Raj, A. A., \& Prastiwi, D. F. C. (2016). Remaja dan internet. Prosiding SEMNAS Penguatan Individu Di Era Revolusi Informasi, 2008, 311-319. 
https://publikasiilmiah.ums.ac.id/bitstream

Hapsari, M., \& Ghozali, I. (2006). Pengaruh Teknologi Informasi Berbasis Sumber Daya terhadap Kinerja Perusahaan. Jurnal Maksi, 6(1), 60-68.

Hunter, J. D., Silvestri, K. N., \& Ackerman, M. L. (2018). Feeling Like a Different Kind of Smart": Twitter as Digital Literacy Mediates Learning for Urban Youth and Literacy Specialist Candidates. School-University Partnerships, 11(1), 36-45.

Idris. (2015). Efektifitas Penggunaan Teknologi Informasi dan Komunikasi dalam Pembelajaran Pendidikan Agama Islam. Potensia: Jurnal Kependidikan Islam, 14(2), 175-190.

Ihsan, M. (2016). Pengaruh terpaan media internet dan pola pergaulan terhadap karakter peserta didik. Tsamrah Al-Fikri, 10, 103-120.

Jang, B. G., Henretty, D., \& Waymouth, H. (2018). A pentagonal pyramid model for differentiation in literacy instruction across the disciplines. Journal of Adolescent \& Adult Literacy, 62(1), 45-53.

Kanematsu, H., \& Barry, D. M. (2016). STEM and ICT education in intelligent environments. Springer.

Khotijah, S. (2015). Pembatasan Penggunaan Internet pada Anak-Anak di Bawah Umur. Faktor Exacta, 6(3), 241-252.

Koutamanis, A., Heuer, J., \& Könings, K. D. (2017). A visual information tool for user participation during the lifecycle of school building design: BIM. European Journal of Education, 52(3), 295-305.

Kuss, D. J., \& Griffiths, M. D. (2011). Online social networking and addiction: A review of the psychological literature. International Journal of Environmental Research and Public Health, 8(9), 3528-3552.

Kusuma, D. F., \& Sugandi, M. S. (2019). Strategi Pemanfaatan Instagram Sebagai Media Komunikasi Pemasaran Digital yang Dilakukan oleh Dino Donuts. Jurnal Manajemen Komunikasi, 3(1), 18. https://doi.org/10.24198/jmk.v3i1.12963

Lankshear, C., \& Knobel, M. (2015). Digital literacy and digital literacies: Policy, pedagogy and research considerations for education. Nordic Journal of Digital Literacy, 9, 8-20.

Lestari, S., Kurnianingsih, I., \& Wardiyono, W. (2018). Pengukuran Kemampuan Literasi Digital Orang Tua Menggunakan Instant Digital Competence Assessment (Instant DCA). Bibliotech: Jurnal Ilmu Perpustakaan Dan Informasi, 3(2).

Listyanto, A. D., \& Munadi, S. (2013). Pengaruh pemanfaatan internet, lingkungan dan motivasi belajar terhadap prestasi belajar siswa SMK. Jurnal Pendidikan Vokasi, $3(3)$.

Livingstone, S., Van Couvering, E., \& Thumim, N. (2014). Converging traditions of research on media and information literacies: disciplinary, critical, and methodological issues. Handbook of Research on New Literacies, 4, 103-132.

Maheswari, J., \& Dwiutami, L. (2013). Pola Perilaku Dewasa Muda yang Kecenderungan Kecanduan Situs Jejaring Sosial. JPPP-Jurnal Penelitian Dan Pengukuran 
Psikologi, 2(1), 51-62.

Marini, A., Safitri, D., \& Muda, I. (2018). Managing school based on character building in the context of religious school culture (Case in Indonesia). Journal of Social Studies Education Research, 9(4), 274-294. https://doi.org/10.17499/jsser.11668

Masni, M., \& Hamid, S. F. (2018). Determinan Perilaku Seksual Berisiko pada Remaja Makassar (Studi Kasus Santri Darul Arqam Gombara dan SMAN 6). Media Kesehatan Masyarakat Indonesia, 68. https://doi.org/10.30597/mkmi.v14i1.3699

Mauludin, M. A., Alim, S., \& Sari, Vi. P. (2016). Cerdas dan Bijak dalam Memanfaatkan Media Sosial di Tengah Era Literasi dan Informasi. Jurnal Aplikasi Ipteks untuk Masyarakat, 5 (1), 34-37.

McLean, C. A. (2010). A space called home: An immigrant adolescent's digital literacy practices. Journal of Adolescent \& Adult Literacy, 54(1), 13-22.

Mucharomah, M. (2017). Guru di era milenial dalam bingkai rahmatan lil alamin. Edukasia Islamika, 172-190.

Mustofa, M., \& Budiwati, B. H. (2019). Proses Literasi Digital terhadap Anak: Tantangan Pendidikan di Zaman Now. Pustakaloka, 11(1), 114-130.

Muyasaroh, Ladamay, O. M. M. A., Mahfud, C., Mustakim, \& Sejati, Y. G. (2020). The utilization of gadget in maintaining prophetical values in millennial generation. International Journal of Psychosocial Rehabilitation, 24(4), 5602-5615. https://doi.org/10.37200/IJPR/V24I4/PR201655

Nicholas, H., \& Ng, W. (2019). Mobile Digital Literacy of Australian Adolescent Students. International Journal of Digital Literacy and Digital Competence (IJDLDC), 10(3), 32-48.

Nicolaou, C., Matsiola, M., \& Kalliris, G. (2019). Technology-Enhanced Learning and Teaching Methodologies through Audiovisual Media. Education Sciences, 9(3), 196.

Nur, M. (2019). Literasi Digital Keagamaan Aktivis Organisasi Keagamaan di Madrasah Aliyah Negeri (MAN) di Kota Bandung. Jurnal SMART (Studi Masyarakat, Religi, Dan Tradisi), 5(1), 1-14.

Nurjanah, E., Rusmana, A., \& Yanto, A. (2017). Hubungan literasi digital dengan kualitas penggunaan e-resources. Lentera Pustaka: Jurnal Kajian Ilmu Perpustakaan, Informasi Dan Kearsipan, 3(2), 117-140.

Nurliah, N. (2018). Konvergensi dan Kompetisi Media Massa dalam Memenangkan Pasar di Era Media Digital di Makassar. Jurnal Dakwah Tabligh, 19(1), 106-118.

Pancarrani, B., Amroh, I. W., \& Noorfitriana, Y. (2017). Peran Literasi Orang Tua dalam Perkembangan Anak. BIBLIOTIKA: Jurnal Kajian Perpustakaan Dan Informasi, 1(2), 23-27.

Perdana, A. (2019). Generasi Milenial dan Strategi Pengelolaan SDM Era Digital. Jurnal Studi Pemuda, 8(1), 75-80.

Pratiwi, N., \& Pritanova, N. (2017). Pengaruh literasi digital terhadap psikologis anak 
dan remaja. Semantik, 6(1), 11-24.

Rahmatullah, R., \& Said, A. (2019). Implementasi Pendidikan Karakter Islam di Era Milenial Pada Pondok Pesantren Mahasiswa. TaLimuna: Jurnal Pendidikan Islam, 8(2), 37-52.

Retnowati, Y. (2015). Urgensi literasi media untuk remaja sebagai panduan mengkritisi media sosial. Jurnal Perlindungan Aanak Dan Remaja. AKINDO. Yogyakarta.

Rodríguez-De-dios, I., Igartua, J. J., \& González-Vázquez, A. (2016). Development and Validation of a Digital Literacy Scale for Teenagers. In ACM International Conference Proceeding Series (Vol. 02-04-November-2016, pp. 1067-1072). Association for Computing Machinery. https://doi.org/10.1145/3012430.3012648

Rose, A. J., \& Rudolph, K. D. (2006). A review of sex differences in peer relationship processes: potential trade-offs for the emotional and behavioral development of girls and boys. Psychological Bulletin, 132(1), 98.

S.A.P., R. S., Tobroni, Ishomuddin, \& Khozin. (2020). The Meaning Construction of a Scientific Approach on Teaching Islamic Education. International Journal of Psychosocial Rehabilitation, 24(9), 2525-2532.

Schou Andreassen, C., \& Pallesen, S. (2014). Social network site addiction-an overview. Current Pharmaceutical Design, 20(25), 4053-4061.

Silvana, H., \& Darmawan, C. (2018). Pendidikan literasi digital di kalangan usia muda di kota bandung. PEDAGOGIA, 16(2), 146-156.

Spante, M., Hashemi, S. S., Lundin, M., \& Algers, A. (2018). Digital competence and digital literacy in higher education research: Systematic review of concept use. Cogent Education, 5(1), 1519143.

Sukanto, E. (2011). Pengaruh Internet Financial Reporting dan Tingkat Pengungkapan Informasi Website Terhadap Frekuensi Perdagangan Saham Perusahaan di Bursa. Fokus Ekonomi: Jurnal Ilmiah Ekonomi, 6(2).

Sukmadinata, N. S. (2003). Landasan Psikologi Proses Pendidikan. Remaja Rosdakarya. Suwarsito, S., Sutomo, S., \& Fauziah, D. (2011). Pengembangan Media Pembelajaran Digital Mata Kuliah Geografi Perkotaan dalam Peningkatan Motivasi Belajar Mahasiswa. JUITA: Jurnal Informatika, 1(3).

Tas, B., \& Öztosun, A. (2018). Predictability of Internet Addiction with Adolescent Perception of Social Support and Ostracism Experiences. Turkish Online Journal of Educational Technology-TOJET, 17(4), 32-41.

Vu, V., Warschauer, M., \& Yim, S. (2019). Digital Storytelling: A District Initiative for Academic Literacy Improvement. Journal of Adolescent \& Adult Literacy, 63(3), 257-267.

Wahab, R. A. (2016). Analisis Perkembangan Internet Broadband di Wilayah Perbatasan Provinsi Sulawesi Utara. Jurnal Penelitian Pos Dan Informatika, 6(2), 201-226.

Wahyuningtyas, Y. F., \& Widiastuti, D. A. (2015). Analisis Pengaruh Persepsi Risiko, Kemudahan dan Manfaat terhadap Keputusan Pembelian Secara Online. Kajian Bisnis Sekolah Tinggi Ilmu Ekonomi Widya Wiwaha, 23(2), 112-120. 
Widyaningsih, R., Sumiyem, S., \& Kuntarto, K. (2017). Kerentanan Radikalisme Agama di Kalangan Anak Muda. Prosiding, 7(1).

Wulandari, T. D. (2013). The Needs of Internet Literacy in an Ongoing Process of Economic Stability. Jurnal Ilmu Komunikasi, 10(1). https://doi.org/10.24002/jik.v10i1.153. 